\title{
A SPIRAL AND COLLINEARITY : INVISIBLE GEOMETRICAL RELATIONSHIPS IN THE PLANS OF THE HOUSE WITH THREE COURTS AND THE COURT HOUSE WITH GARAGE BY MIES VAN DER ROHE
}

\author{
螺旋と共線性：ミース・ファン・デル・ローエによる \\ 三つの中庭をもつコート・ハウスとガレージをもつコート・ハウスの \\ 平面に隠れている幾何学的関係
}

Junichi SANO*

佐野潤一

\begin{abstract}
Regarding geometrical relationships closely connected with Mies's architectural principle. "successful relationship," analyses of two well-known court houses of 1934, the House with Three Courts and the Court House with Garage, derived that a so called golden rectangle and collinearity were probably used for making the plans. Especially it is very interesting that Mies utilized a spiral of the whirling squares in a golden rectangle for disposing components in order to achieve the "successful relationship."
\end{abstract}

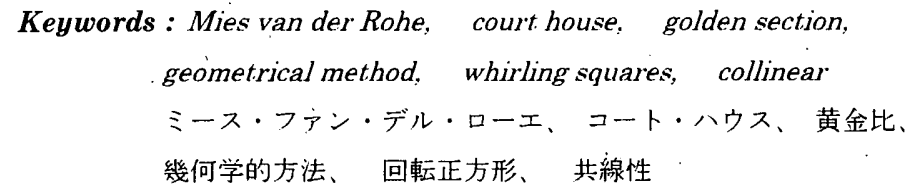

\section{Introduction}

In the book accompanying Mies's 1947 exhibition at MoMA ${ }^{1}$ Philip Johnson introduced the term "court-house" and provided a historical frame and a definition for its concept. ${ }^{2}$ He writes, "From 1931 to 1938 Mies developed a series of projects for "court-house" in which the flow of space is confined within a single rectangle formed by the outside walls of court and house conjoined:"3

The court house is said to be "one of Mies's most elaborately studied themes" 4 and "Mies's most compelling architectural accomplishment of the 1930s."5 There are two well-known court houses dated 1934, the House with Three Courts (Fig.1) ${ }^{6}$ and the Court House with Garage (Fig.5). While the former is orthogonal, the latter is freer, curvilinear. The two are in contrast with each other.

Except the two projects there were several court house projects, however the two were printed in almost all books on Mies in his lifetime.? Further the two plans are also said to be "purely visionary endeavors in which he refined his concept of space for its own sake." 8 The facts show that they were most ideal, refined plans for Mies.

By the way Mies talked about his architectural principle suggesting Alberti's famous definition of beauty. ${ }^{9}$

Mies said: "We shall emphasize the organic principle of order as a means of achieving the successful relationship of the parts to each other and to the whole... We must have order allocating to each thing its proper place." 10 Then the two ideal, refined plans ought to achieve "the successful relationship" and are good examples for investigating it.

However while historical frames for the two court houses have been well examined, the formal essences of them, especially the formal aspects of "the successful relationship," have not yet been investigated.11

Besides in my previous studies ${ }^{12}$ it is found that in each floor plan of Mies's masterpieces in which "the successful relationship" was achieved some specific geometrical relationships, collinearity ${ }^{13}$, a so-called golden section: ${ }^{14}$ and so on, were used for "allocating to each thing 
its proper place." What kinds of geometrical relationships were used in order to achieve "the successful relationship" in the two plans? How was it concretely achieved?

The problems connect with elucidation of Mies's unknown ingenious formal methods for achieving "the successful relationship." Then in this paper to answer the questions both the two plans ${ }^{15}$ are analyzed and considered in detail from the viewpoint of geometrical relationships. From these analyses and considerations it is attempted to develop a better understanding of the formal aspect of "the successful relationship" achieved by Mies's "organic principle of order."

\section{The House with Three Courts}

\subsection{The Plan of the House with Three Courts}

This court house (Fig.1) makes use of three courts. The house proper is a roofed section of the total walled area. It is roughly T-shaped in plan, so that each wing looks out on two courts. The free disposition of freestanding walls recalls that in Mies's Brick Country House of 1924 and the columns are regularly spaced as in his Barcelona Pavilion of 1929. However it is for the first time that Mies produced a complete rectangular enclosure. ${ }^{16}$ Although there can be found Mies's ow precedents. the plan is unique.

What kinds of geometrical relationships between the freestanding walls, the T-shaped interior and the whole rectangular enclosure were used in the unique plan confined within a single rectangle?

\subsection{Collinearity: Relationships between the Interior Components}

First investigate the relationships of the freestanding walls to each other. Regarding the drawing (Fig.2), the line connecting upper end $F$ of vertical, freestanding wall FG and upper end $\mathbf{J}$ of brick wall $\mathbf{J E}$ just passes right end $\mathrm{H}$ of bed room wall $\mathrm{HI}$. That is, the ends $\mathbf{F} . \mathrm{H}$ and $\mathrm{J}$ are collinear. Collinearity relates the main three walls, FG. JE and HI. to each other.

Lower end G. lower-right corner $\mathrm{K}$ of the upper-left middle court and right end $\mathrm{H}$ are just in the same line. collinear. Collinearity also relates walls FG. HI and the middle court to each other.

In the plan the furniture is as conspicuous as the freestanding walls. Then investigating the dinning table, the sofas, the bed and the storage wall, there can be also found many collinearities (Fig.2: FmHJ, LijK, NkO, MnB).

Even if some may be coincidences, it is appropriate to suppose that the Mies probably placed ends or corners of the main components by means of collinearity.

\subsection{A Rectangle of the Whirling Squares, a Golden} Rectangle: Relationships between the Whole Enclosing

\section{Wall and the T-shaped Interior}

Investigate relationships between the whole enclosing wall and the $\mathrm{T}$-shaped interior. A square grid of the pavement. joints shows that the whole rectangular area (Fig.3: $\mathrm{ABCD}$ ) enclosed by the brick walls is 24 by 39 in terms of the grid. The ratio of the long side to the short side of the rectangle is $1: 1.625$, almost of a golden section.

Besides drawing a square on right side $\mathrm{AD}$ of the whole rectangular area $(\mathrm{ABCD})$, its left side, ab, just corresponds to the line passes the center of the fireplace, that is, the middle line between the two rows of the columns in the bar of the T-shaped interior. The line can be said to be the central axis of the living space.

Next drawing a smaller square on upper side Ca of the excess rectangle (CabB), its lower side, de. just corresponds to the centerline of the bedroom in the stem of the $\mathrm{T}$-shaped interior, the centerline is also the middle line between the two rows of the columns.

Third drawing an even smaller square on left side Bd of the excess rectangle (debB), interestingly its right side just corresponds to left side JE of the inner brick wall.

Further drawing a further smaller square on lower side Eb of the excess rectangle (febE), upper side gh just corresponds to the row of the columns.

A spiral figure of squares becoming smaller can be found. For instance a spiral line can be also made of quarter arcs in the whirling squares (Fig.4).

It is quite difficult to suppose that all these facts are coincidences. A rectangle of the whirling squares. a golden rectangle, was probably conceived and used by Mies.

The whole enclosing wall is strictly related to the basic structure of the T-shaped interior by means of a rectangle of the whirling squares, a golden rectangle.

\subsection{A Spiral Revolution: Relationships between the $T$} shaped Interior and the Interior Components

Then what kinds of relationships can be found between the $\mathrm{T}$-shaped interior and the former components related to each other by means of collinearity? The main walls (Fig.4: FG. HI. JE) are placed around a pole within the bathroom, so that they seem to revolve around the pole. Further long transverse terrace $\mathbf{q}$ in the right largest court. the upper bar and stem of the T-shaped interior strengthen this revolution. Not only the pole is quite near the pole of the whirling squares. but also the revolution of the walls just conforms to the revolution of the whirling squares, the spiral movement (Arcs Aa. ad. dE, Eh and hp). Interestingly even the spiral of the stair to the basement floor conforms to the spiral movement (Arc hp).

ls the relation a coincidence or not? In any case there is certainly a relationship between the revolution of the main 


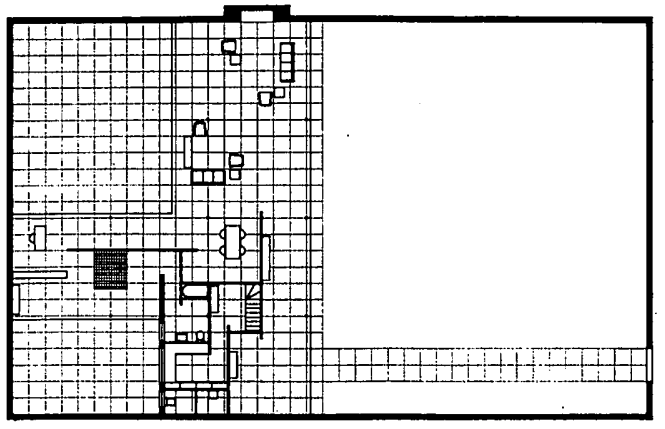

Fig.1 Plan of the House with Three Courts

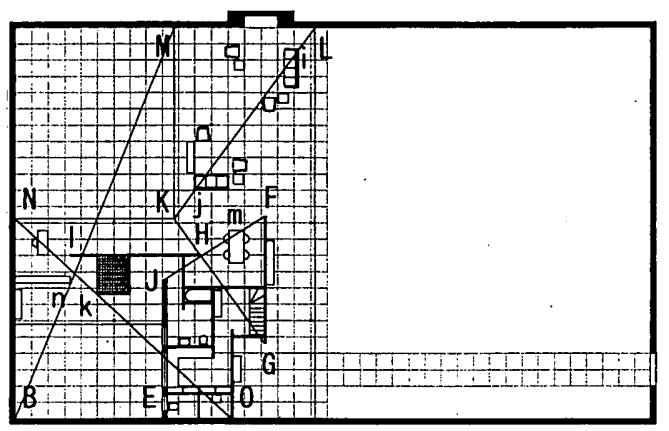

Fig.2 Collinearity in Plan of the House with Three Courts

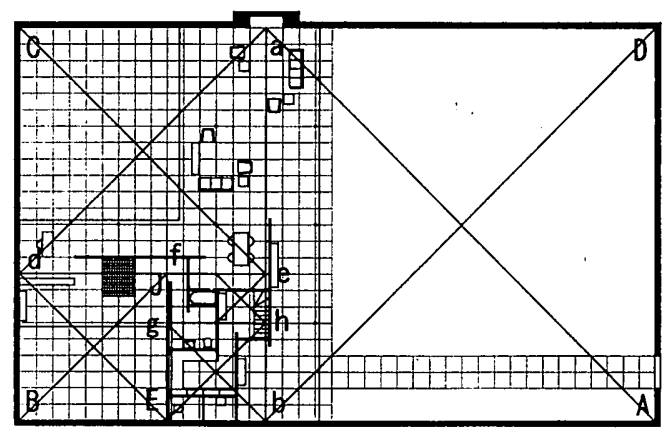

Fig.3 A Rectangle of the Whirling Squares in Plan of the House with Three Courts

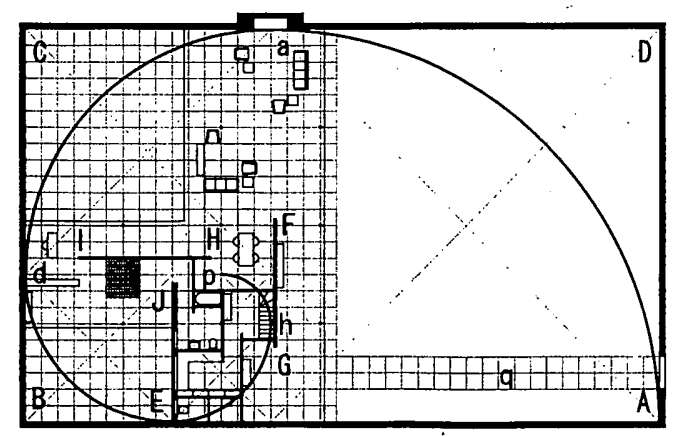

Fig.4 A Spiral of the Whirling Squares in Plan of the House with Three Courts

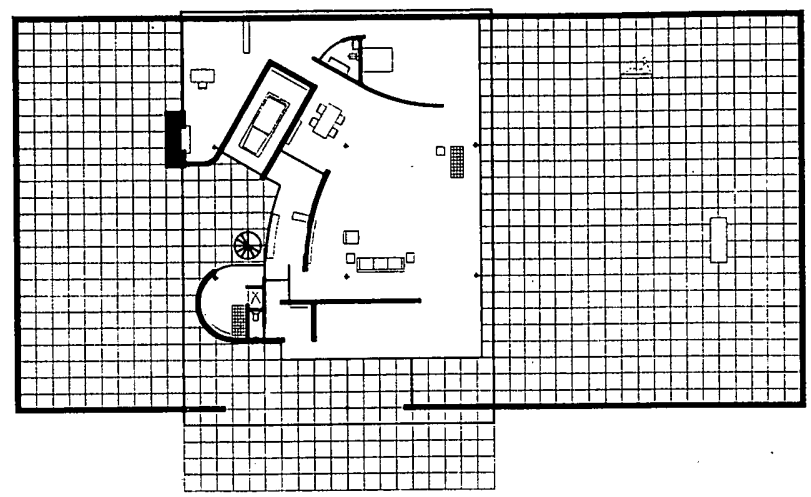

Fig,5 Plan of the Court House with Garage

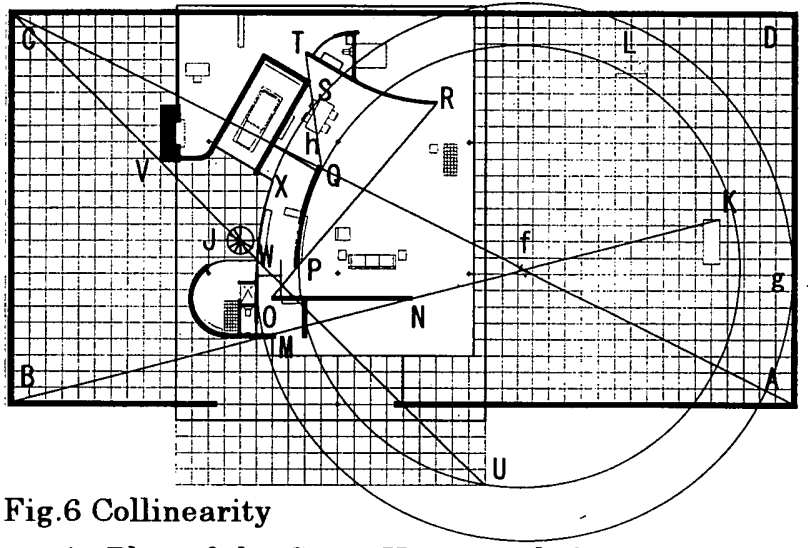

in Plan of the Court House with Garage

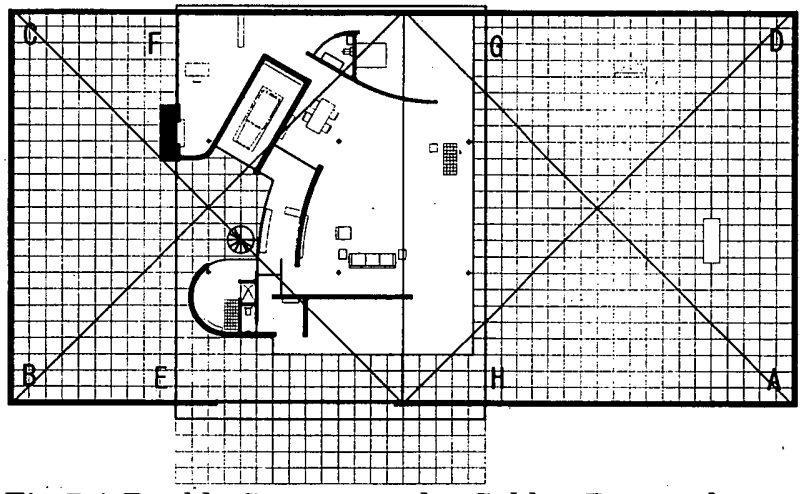

Fig.7 A Double Squares and a Golden Rectangle in Plan of the Court House with Garage

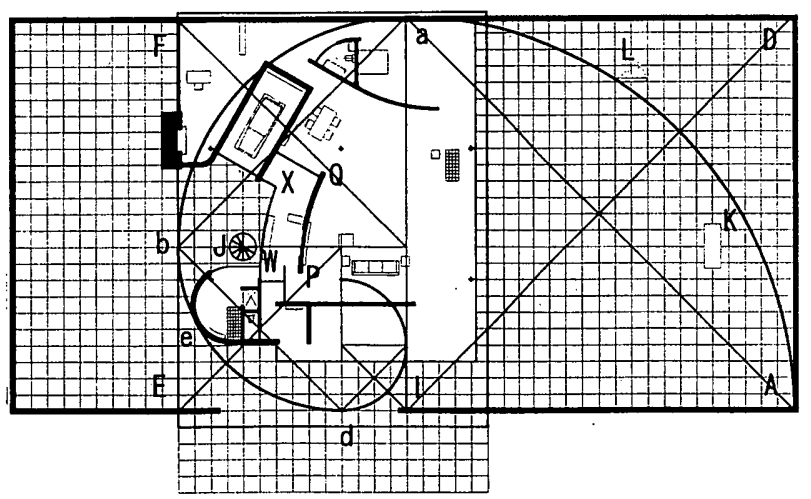

Fig.8 A Spiral of the Whirling Squares

in Plan of the Court House with Garage 
components and the spiral whirling of the basic structure of the T-shaped interior.

Then how about the Court House with Garage?

\section{The Court House with Garage}

\subsection{The Plan of the Court House with Garage}

The house (Fig.5) has a large court on either side. Its whole rectangular area is longer, larger than the former. ${ }^{17}$ Besides the curvilinear plan is said to have been derived from the painting of Kandinsky and so no. ${ }^{18}$ The sweeping walls seem to be bended in order to accommodate a garage forced into the building perpendicular to a diagonal axis. ${ }^{19}$ Interestingly the garage forced into the building and the circular wall can be found in the ground floor plan of Le Corbusier's Villa Savoye of 1930.20 The garage and curved wall might be directly derived from Le Corbusier's Savoye. And the curvilinear interior might come from the floor plans by Hugo Häring who worked with Mies in the 1920 s. $^{21}$ Further curved forms can be also found in Mies's own designs, the semicircular wall enclosing the dinning area of the Tugendhat House of 1930, the sweeping legs of his Barcelona Chair of 1930 and so on. ${ }^{22}$

Whatever precedents can be found. the plan of the Court House with Garage is also quite unique. Then investigate relationships between the sweeping walls, the curvilinear interior and the whole rectangular enclosure.

\subsection{Collinearity: Relationships between the Components}

First investigate relationships between the main interior components (Fig.6). The line connecting left end $O$ of the $\mathrm{T}$-shaped screen wall NO and right end R of Y-curved wall RT partitioning the bed room from the living just passes lower end $\mathrm{P}$ of curved wall $\mathrm{PQ}$. Collinearity relates the main three walls. NO, RT and PQ. to each other. Lpper end $\mathbf{Q}$. lower corner $\mathbf{h}$ of the dinning table, upper-right corner $\mathbf{S}$ of the garage and left end $\mathbf{T}$ are also collinear. Interestingly the collinearity between the main walls and the dinning table (QhST) is the same relationship as the former (Fig.2: FmHJ). Almost all the conspicuous interior components connect with each other.

Investigate exterior components. The extension line of $\mathrm{BM}$ just passes $\mathrm{N}$ and upper-right corner $\mathrm{K}$ of the exterior furniture. The line connecting corner $\mathrm{C}$ of the whole and lower-right corner $U$ of the porch just passes center $J$ of the exterior spiral stair and corner $\mathrm{V}$ of the fireplace. ${ }^{23} \mathrm{Upper}$ end $\mathrm{Q}$ of curved wall in the living area is in diagonal $\mathrm{AC}$ of whole walled rectangle $\mathrm{ABCD}$. That is. corners $\mathrm{A}$ and $\mathrm{C}$ of the whole rectangle and end $Q$ are collinear.

Besides curved wall $P Q$ is an arc. Interestingly invisible center $\mathbf{f}$ of the arc's circle is also just in diagonal $\mathrm{AC}$ of the whole rectangular area. Further corner $U$ of the porch and statue $L$ in the court are in the circumference of this circle

Arc glass wall WX's circle just inscribes the internal side of the right brick wall at g. Even an arc glass wall is strictly connected with the whole brick wall. ${ }^{24}$

So, to summarize, not only the interior and exterior components, but also the invisible center of arc wall's circle are closely connected with each other by means of colliniearity.

\subsection{A Double Square and a Golden Rectangle: Relation- ships between the Whole Enclosing Wall and the Interior} A square grid of the pavement joints show's that the whole rectangular area except the lower projection of the porch enclosed by the brick walls is 24 by 48 in terms of the square units of the grid (Fig.7), that is, a double square.

The rectangle of the right large court plus the roofed section is 24 by 38 in terms of the square units. The ratio is $1: 1.58$. It is approximately a golden section. Further the ratio of the area enclosed by the internal sides of the brick walls (Fig.7: AEFD) is approximately 1:1.6.25 This area (AEFD) more approximates to a golden rectangle

Interestingly the vertical center line (Fig.7: GH) of this golden rectangle (AEFD) is just the right side of the roofed section. Roofed section except the lower projection of the porch is just a half (HEFG) of this golden rectangle (AEFD). It shows that Mies probably conceived these rectangles.

Besides a golden rectangle has a close geometrical relationship to a square or a double square. It can be easily constructed from a square or a double square. ${ }^{26}$ The approximation to a golden rectangle and this geometrical relationship derive that in this plan a golden rectangle was conceived by Mies.

The whole rectangular area, the two courts and the interior are related to each other by means of a double square and a golden rectangle.

\subsection{A Spiral: Relationships between the Curved Interior and the Components}

Drawing the whirling squares in this golden rectangular area (Fig.8: AEFD) and a spiral line made of quarter arcs in the whirling squares, it is found that the whirling squares and the spiral line conform to the components.

The fence (I) between the porch and the right large court is just in the left side of the largest square of the whirling squares in this golden rectangular area. The center of the exterior spiral stair (J) is also just in the lower side of the second square. The column at the porch also just stands at lower-right vertex $\mathbf{d}$ of the third square. Thus the whirling squares of the golden rectangular area (AEFD) relate to the components.

Further interestingly the main components are just placed along the spiral line. Arc Aa approximately 
conforms to the exterior furniture (K) and statue (L). Arc ab conforms to the curved wall of the bathroom, the slanting walls of the garage, curved wall PQ and curved glass wall WX. Arc bd not. only conforms to the circular wall enclosing the servant room, but also just contacts it at e.

The same spiral as in the former plan (Fig.4) can be found in this plan (Fig.8). It is difficult to suppose that both the two spirals are coincidences at the same time. A spiral of the whirling squares was probably conceived and used by Mies.

Almost all the main components are related to the golden rectangle of the right large court plus the roofed section by means of the spiral line of the whirling squares.

\section{Conclusion: A Spiral and Collinearity}

In the Plan of the House with Three Courts the interior walls and furniture are strictly related to each other by means of colliniearity (Fig.2), the whole enclosing wall is related to the T-shaped interior by means of a rectangle of the whirling squares, a golden rectangle (Fig.3), and the T-shaped interior to the main freestanding walls by means of the spiral revolution of the whirling squares (Fig.4).

On the other hand in the Plan of the Court. House with Garage almost all the components are also related to each other by means of colliniearity (Fig.6), the whole enclosing wall is related to the curved interior by means of a double square and a golden rectangle (Fig.7), and the golden rectangular area to the main components by the spiral line of the whirling squares (Fig.8).

Although at first glance the two court house plans look very contrastive, there can be found the same invisible geometrical relationships, a spiral and collinearity.

A free disposition of components is liable to become too scattered and perhaps not to achieve "the successful relationship." However in the two plans collinearity unites almost all the components each other, and a spiral revolution of whirling squares keeps them in a regular movement, and does from becoming too scattered. Further the spiral also relates the components to the whole enclosing wall.

The spiral and collinearity "allocating to each thing its proper place" concern with the main forms of the two plans. Then it is reasonable to suppose that they strictly connect. with the formal aspects of "the successful relationship".

They can be said to be Mies's unknown ingenious formal methods for achieving "the successful relationship."

Especially it is very interesting that in Miess designs a golden rectangle was used not only for a specific proportion. ${ }^{27}$ but also in order to produce a spiral revolution of its whirling squares for unity of the parts and close relationship of the parts to the whole. Then I should report this conclusion for developing a better understanding of "the successful relationship" achieved by Mies's "organic principle of order."

\section{Notes}

1 Johnson, C. Philip, MIES VAN DER ROHE, New York. 1947. 2 Riley corrects Johnson's explanation. He writes "The court-house was not the dominant motif in Mies's architectural practice of the 1930 s but an abstract problem within his teaching." (Riley. Telence, \& Bergdoll, Barry, eds., MIES IN BERLIN, New York, 2001, p.332). 3 Ibid., p.104. 4 Drexler, Arthur, Mies van der Rohe, New York, 1960, p.49. 5 Riley. Telence, \& Bergdoll, Barry, eds., op.; cit. p.332. 6 In my previous study (Sano J. "ON THE GOLDEN RATIO IN THE PLANS OF THE HOUSE WITH THREE COURTS AND IIT CHAPEL." Journal of Architecture, Planning and Environmental Engineering. AIJ. No.453. 1993) it is found that a rectangle of the whirling squares was used to make the basic structure of the plan. 7 For instance. P. Johnson's Mies van der Rohe of 1947. A. Drexler's Ludwig Mies van der Rohe of 1960 , W. Blaser's Mies van der Rohe of 1965 and so on. 8 Schulze. Franz, MIES VAN DER ROHE: A Critical Biography: Chicago and London, 1985. p.192. 9 Taking it into account that Mies studied Alberti's books (Hirberseimer, MIES VAN DER ROHE, Chicago, 1956, p.36). his words might come from Albertis following famous definition of beauty. "An Enquiry of the utmost Difficulty ; for whatever the Property be which is so gathered and collected from the whole Number and Nature of the several Parts, or to be imparted to each of them according to a certain and regular Order, or which must be contrived in such Manner as to join and unite a certain Number of Parts into Body or Whole, by an orderly and sure Coherence and Agreement of all those Parts : Which Property is what we are here to discover : it is certain, such a Property must. have in itself something of the Force and Spirit of all the Parts with which it is either united or mixed, other wise they must jar and disagree with each other, and by such Discord destroy the Uniformity or Beauty of the Whole." (Alberti, The Ten Books on Architecture, Ed. Rykwert, Joseph. London 1955, p.194). 10 Mies's inaugural address as director of architecture at Armour Institute of Technology in 1938. "..... We shall emphasize the organic. principle of order as a means of achieving the successful relationship of the parts to each other and to the whole. And here we shall take our stand. The long path from material through function to creative work has only a single goal: to create order out of the desperate confusion of our time. We must have order 
allocating to each thing its proper place and giving to each thing its due according to its nature. ..." (Swenson, Alfred, Chang and Pao'Chi, eds., ARCHITECTURAL EDUCATION AT IIT 19381978. Chicago, 1980, p.28). 11 Following the court house's historical frame and a definition for its concept by Johnson (Johnson, op. cit., p.96). Wolf Tegethoff writes the social environment and the starting point of the court house, "It has seemed likely that Mies, practically forced into inactivity by the restrictive cultural politics of the National Socialist, was here attempting to perfect a concept that had already made its appearance, essentially in the House at the Berlin Building Exposition. Probably first conceived within in the framework of the Bauhaus curriculum as an assignment for advanced architecture students, the idea of the Court House seems to have originated during the time of his teaching in Dessau, which would confirm the date of 1931 as' a starting point." (Tegethoff. Wolf, MIES VAN DER ROHE: Die Villen und Landhausprojekte, Bonn. 1981, pp.124-126). Lately Riley corrected Johnson's explanation for the court house's historical frame and the printed drawings in Johnson's book. (Riley: Telence. \& Bergdoll, Barry. eds., op. cit. p.330-337). 12 Sano J. "ON THE GOLDEN RATIO..." op. cit., "COLLINEARITY'. SIMILARITY AND EQUIRATERAL TRIANGLES IN THE OPEN PLANS OF IITSS CROWN HALL, THE RON BACARDI COMPANY ADMINISTRATION BUILDING AND THE NEW NATIONAL GALLERY BY MIES VAN DER ROHE." Ibid., No.565, 2003, "FROM COLLINEARITY THROUGH SIMILARITY TO EQUIRATERAL TRIANGLES TRANSITION OF GEOMETRICAL RELATIONSHIPS IN THE OPEN PLANS OF MIES VAN DER ROHES PROJECTS IN THE 1940'S." Ibid.. No.579, 2004. 13 When ends or corners of different components are in the same line, they are collinear. 14 Expressed as a formula: $A: B=B:(A+B)$ and expressed as a ratio of irrational numbers: $1: 1.618$. This is the formula of the celebrated golden section, uniquely reciprocal relationship between two unequal parts of a whole, in which the small part stands in the same proportion to the large part stands to the whole. 15 The Court House with Garage (Fig.5) is dated 1934, but drawn by Danforth in America from an existing drawing by Mies (Riley, Telence, \& Bergdoll. Barry, eds.. op. cit. p.331). The Court House with Garage (or the Court House with Curved Wall Elements) is also dated 1934, but probably drawn in America (Ibid.. p.332). Although there are plans in which trees are drawn in the courts. the possibly original plans (Ibid., p.295. Drexler. Arthur, ed., An Illustrated Catalogue of the Mies van der Rohe Drawings in MoMA, vol.t. New York, 1986, p.78) have not them. So in this paper the plans without trees are analyzed. 16 Although the interior is certainly similar to those in the Barcelona Pavilion of 1929. the Tugendhat House of 1930 and the Berlin Building Exposition's model house of 1931. they are not confined within a single rectangle. 17 Although both the drawings (Fig.1,5) have not. dimensions. their dimensions can be approximately derived from the sizes of the drawings. The House with Three Courts is $24 \mathrm{~m} \times$ $39 \mathrm{~m}$ and the Court House with Garage is $24 \mathrm{~m} \times 48 \mathrm{~m}$. Namely either of the grids seems to be $1 \mathrm{~m} \times 1 \mathrm{~m}$ (Drexler, Arthur, ed., $A n$ Illustrated Catalogue..., op. cit, p.78, p.70). 18 For instance, Drexler writes, "...the Court House with Garage might almost have derived from the painting of Kandinsky" (Drexler, op. cit, p.23). In fact Mies had the painting of Kandinsky (Barnett, Vivian, "The Architect as Art Collector," in Lambert, Phyllis ed., Mies in America, New York, 2001, p.107). 19 By the way Michel van Beuren, whom Mies tutored privately in $1934-35$ produced a design remarkably similar to the basic scheme of Mies's drawing. Mies's (Fig.5) and van Beuren's are so similar that they arise questions as to the precise relationship between the two projects. While it may never be clear what relationships exist between them. it is clear that they represent an interlude shared by teacher and student (Riley. Telence, \& Bergdoll, Barry: eds.: op. cit., p.332). 20 In Savoye three cars are accommodated and conversely swing (Brooks, H. Allen, ed., The Le Corbusier Archive, VII: New York. 1984. p.251.). 21 For example Gut Garkau of 1929 a complete new house (Jones. B. Peter, Hugo Häring: The Organic versus the Geometric, Stuttgart/London, 1999, p.65). 22 For instance. the circular disposition of curtains in the Silk Exhibition of 1927 and the curved large entrance hall in Reiches Bank project of 1933. 23 Interestingly CU is a diagonal of a square. That is, the rectangle enclosing the left court. the roofed area and the porch is just square. 24 At first glance center of the circle of $P Q$ and the center of WX are same, however they are strangely a little different from each other. Difference between the upper part of arc WX and that of arc PQ is a little smaller than that between the lower part of WX and of are PQ. So that the two ares and the side wall of the garage are united. If the centers are same. the two arcs are more united each other than with the side wall of the garage. The unity of the three is scattered. We can find here Mies's ingenuous formal method. 25 Besides the upper side of the double square. the most upper line of the grid, is the centerline of the upper horizontal exterior wall. The lower side of it is also the centerline of the lower wall. However the right and left sides of the double square are the internal sides of the vertical exterior walls. 26 Using a midpoint of a base of a square drawing an arc with a radius of a diagonal of half the square, the crossing in the extension of the base makes a long side of a golden rectangle. 27 See note 6 .

\section{Sources of Illustrations}

(This paper includes no reproduction of the original drawings. All figs have been redrawn or drawn by Sano.)

Fig.1 Drexler, Arthur. ed., An Illustrated Catalogue of the Mies van der Rohe Drawings in MoMA. vol.4. New York, 1986, p.78. Fig.5 Ibid., p.70. 


\section{和文要約}

コート・ハウスという言葉はニューヨーク近代美術館での 1947 年ミース・ファン・デル・ローエ展に添えたフィリッブ・ ジョンソンによるミースのモノグラフにおいて初めて登場し、 その一連の作品はミースが「熱心に追求したテーマの一つ」 で、1930 年代の最も際立った業績」などと評価されている。 それらの中に、1934 年の「三つの中庭を持つコート・八ウス」 と「ガレージを持つコート・八ウス」(Fig.1,5)二作がある。前 者怄直線的、後者は曲線的と対照的ではあるが、両者はミー ス存命中のほとんどの作品集などに掲載され、さらには「ミ 一スの空間概念の洗練化、理想化」などと賞賛もされている。 つまり こつのコート・ハウスはミースにとって、とりわけ満足 のいく作品であったと判断できよう。

さてミースはアルベルティーの著名な美の定義を思わせる 自らの建築原理について語っている。我々は部分相互、及び 部分と全体との首尾よき関倸を達成する手段としての有機的 秩序の原理を強調する。，西我々付個々の要素に、それらに相 応しい場所を割り当てる秩序を持たねばならない」とすれば、 洗練された理想的な二つのコート・八ウスは当然この「首尾よ き関倸!を十分に達成しているはずであり、まさにその解明 には最適の事例と言えよう。

二つのコート・ハウスの歴史的な背景などはななりよく調 ベられている。しかし形態的な本質、特に「首尾よき関倸」 の形態的側面はこれまでほとんど言及されていない。

筆者はこ犺までの研究で、ミ一スの傑作とされる諸作品に ついて、個々の要素に、それらに相応しい場所を割り当てる! ために、共線性や黄金分割などの特別な幾何学的関倸が使用 された可能性を導出している。

さて二つのコート・ハウスでは「首尾よき関倸」達成のため にいかなる幾何学的関倸が使用されたのか。またi首尾よき 関倸」は具体的にはどのように達成されているのか。

この問題はミースの知られざる設計手法の解明につながっ ている。そこで本稿では二つのコート・ハウスの平面を幾何学 的関倸の観点から分析、考察し、問題の解明を試みた。

「三つの中庭を持つコート・ハウス」(Fig.1)の平面は、棟瓦造 田園住宅案の壁の配置やバルセロナ・・バビリオンの規則的に 配置された柱を思わせるが、建物全体を矩形の壁が完全に囲 むやり方は初めてで、平面全体はュニークである。

一見自由な配置に見えるが、屋内の主要な独立壁(Fig.2:FG， $\mathrm{HI}, \mathrm{JE})$ 端部は一直線上に並んでいる(FHJ)、つまり共線的 である。さらにファニチャーの角や建物の主要な角なども一 直線上にある。つまり個々の部分は共線性によって関係付け られていると言える。

外周壁に囲まれた敷地全体(Fig.3:ABCD)は床目地のグリ ッド数で $24 \times 39$ 、その比は 1:1.625、黄金比と言える。てし て敷地右短辺上に正方形をつくると、その左辺はち上うど暖 炬の中心、つまりリビングの中心軸に一致する。次に残りの エリアの上方短辺上に正方形をつくると、その下辺は寝室の 中心軸に一致する。さらに残りのエリアで同様な正方形をつ
くるとその一辺はバスルームと小コートを分ける煉瓦壁の左 面に一致し、さらに正方形をつくると、一辺は柱の軸線に一 致する。これらの一致が偶然であるとは考えられない。つま り敷地全体の矩形と $\mathrm{T}$ 字型の建物部分の基本構造は黄金矩形 の回転正方形によって関倸付けられていると言える(Fig.3)。

最後に敷地全体、 $\mathrm{T}$ 宇型部分両者と屋内の独立壁などとの 関係はどうか。三つの主要な壁(Fig.4:FG, HI,JE)はバスルー ムあたりを中心に回転するように配置されているが、玄関へ 伸びるアブローチ $(\mathrm{q})$ と $\mathrm{T}$ 字型平面がこの回転を強めているよ うに見える。興味深いことにこの回転は全体の回転正方形の 螺旋運動上まさに同調しており、両者の関倸が推測できる。

「ガレージを持つコート・ハウス」(Fig.5)の平面と曲線要素 については、ル・コルビュジェのサボア邸やフーゴー・ヘー リングの作品、さらにはミース自身のトゥーゲントハット邸 からバルセロナ・チェアーの脚までさまざまな先例を指摘で きるが、平面全体はあくまでもユニークである。

特徴的なカーブした壁の端部やガレージの角は一直線に並 んでいる(Fig.6:OPR, QST)。外周壁の角や屋外ファニチャー なども共線的である。興味深いことにリビングのカーブした 壁は円弧をなすが、その円弧の円の中心(f) はちょうど敷地全 体の対角線(AC)上にあり、これも共線的である。壁や屋外フ アニチャー、さらに壁のカーブの中心点さえ共線性によって 緊密に関倸付けら机ている。

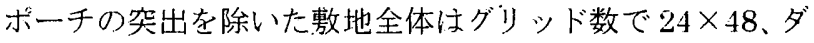
ブルスクエアである(Fig.7)。また外周壁に囲まれた右コート と屋根の架かつたエリア(AEFD)の短辺長辺比は 1:1.6で黄金 比に近く、またこの矩形を二分する中心線 $(\mathrm{GH})$ はちょうど屋 根の右端に一致する。ここでも建物部分の配置に黄金矩形が 介在した可能性が導出できる。

この矩形(Fig.8:AEFD)内に回転正方形を描いていくと各 正方形の辺の位置にいくつかの要素が一致する。さらに回転 正方形の螺旋を描くとそのカーブは主要な要素など、つまり 屋外ファニチャー、バスルームのカーブした壁、斜めのガレ ージの壁、リビングとキッチンのカーブした壁、使用人室の 半円状の壁、ポーチの柱とことごとく対応、同調している。 これらが全くの偶然とは考え難い。

前例の螺旋と諸要素上の関倸をも考え合わせると、両案上 もに黄金矩形の回転正方形が介在したと判断できる(Fig.4,8)

両者は一見対照的に見えるが、以上のようにそこには同じ 見えざる幾何学的関倸、つまり螺旋上共線性の存在が導出さ れた。自由な構成はバラバラな印象につながりやすいが、両 平面においては共線性が個々の部分のつながりをつけ、回転 正方形の螺旋がそれらを全体的な一つのまとまりにし、かつ 全体とも関倸付けている。

螺旋と共線性は両平面の形態上の特徵であり、首尾よき関 倸」につながっていると言えよう。ミース作品において黄金 比が特別なブロボーションの実現ばかりか、回転正方形の螦 旋によって個々の部分をまとめ、かつ全体とも関倸付けてい ることは特に興味樑い。

（2004年 7 月 5 日原稿受理， 2004 年 10 月 25 日採用決定） 